\title{
DIE NAME VAN PETRUS EN I PETRUS
}

Die afgelope aantal jare het 'n ryk oes aan studies oor die persoon en die rol van Petrus opgelewer. Een van die redes vir die hernude belangstelling in die primus onder die Twaalf, is ongetwyfeld die hernuwing en die erns van die gesprek tussen Rome en die Protestantisme. Van protestantse kant het hierdie belangstelling opgelewer Oscar Cullmann se Pierre, Disciple, A.pôtre et Martyr, Paris 1952, en van Roomse kant Paul Gaechter se ewe onderhoudendeversameling van studies, Petrus und seine Zeit, In $s \mathrm{r}$ ck 1958. Die rol van Petrus in die oergemeente ontvang ook 'n vars ondersoek in die op-en-top kommentaar van Haenchen in sy Apostelgeschichte, Serie Meyers Kommentar zum Neuen Testament, en die historiese ontleding van die eerste agt hoofstukke van Handelinge deur Bo Reicke. Maar merkwaardig bly die terughouding teenoor die 1ste Brief van Petrus. Cullmann, in sy genoemde werk, laat die outeurskap daarvan versigtig in die midde. Trouens geeneen van die moderne outeurs waag hulle aan 'n definitiewe uitspraak nie. En die laaste wat met aanspraak op wetenskaplike redenering geboekstaaf staan is: tengunste van die petriniese outeurskap van I Petrus, W. C. van Unnik, De Verlossing in I Petrus 1:18 en 19; teen die petriniese oorsprong, R. Knopf, H. Windisch, F. W. Beare. 'n Nuwe omvattende kommentaar op I Petrus is in 
elk geval besonder nodig. Die debat oor die historisiteit van die naam „Petrus", die eerste woord van die brief, duur voort en vir die Inleidingswetenskap bly die Rots wat daarin verwoord is, nog steeds ' $n$ struikelsteen. In die brief ontbreek namelik oortuigende persoonlike verwysinge wat die aanspraak op die naam in die openingssin regverdig. Oral daarenteen, in die gang van die brief, duik daar situasies, woordgebruike en teologiese voorstellinge op wat juis nie kenmerkend is van Petrus nie maar eerder van Paulus indien wel van enige bekende nieutestamentiese persoonlikheid. Ondersoekers van 'n half-eeu gelede en meer het al op dié sonderlinge verskynsel gewys. Die engelse eksegeet, Bigg, in die behandeling van die brief in die International Critical Commentary tel byvoorbeeld in die vyf hoofstukkies waaruit die brief bestaan, soveel as twee-en-sestig hapax legomena. Dit rym moeilik met Hnd. 4:13 se verw ysing na Petrus die Galileër as 'n agrammatos kai idiōtes. Maar dit word bepaald vreemd wanneer blyk dat veertig van die sestigtal seldsame woorde afkomstig is uit die Septuaginta en ander Griekse vertalinge van die Ou Testament. Waarom sou Petrus dan spesiaal so bedrewe gewees het in die Griekse Ou Testament? Dit val onder dié omstandighede ook meer in die oog dat die outestamentiese sitate in die brief oorwegend herlei kan word tot die Septuaginta met sy Apokriewe en al. In pleks van hierdie opvallende aanleuning aan die Septuaginta sou mens inteendeel 'n paar interessante hebraismes verwag het in 'n brief van Petrus. Maar met die moontlike uitsondering van laos eis peripoiesin in 2:9, ontbreek alle hebraismes. Om die waarheid te sê-Knopf, $W^{\prime}$ indisch en andere het al daarop gewys -die outeur van hierdie brief het Grieks met die juistheid en die aanvoeling van die ontwikkelde kenner geskryf. Sy teenstellende men.. de's is in perfekte orde en sy strofe-indeling voorbeeldig. $\mathrm{Hy}$ is ' $\mathrm{n}$ stilisd.w.s. 'n Griekse stilis. Was dit nie vir die ontbreek van die soepele aanwending van die partikel, an, nie moet mens Grieks as sy moedertaal aanvaar. En selfs die gemis kan te wyte wees aan lokale spreekgewoonte.

Om die raaisel te verswaar, sê die tradisie en suggereer die kriptoniem, Babilon, in 5:13 dat die brief uit Rome geskryf is. Maar anders as die Evangelie volgens Markus wat regtig uit Rome kom, bevat I Petrus nie latinismes nie-nie eers een nie.

Nou maak 5:12 Silvanus verantwoordelik vir die optekening. Oppervlakkig gesien, verdwyn hiermee meeste van die taalkundige enigma's; in werklikheid voer hierdie opmerking die oplossing nog verder uit ons handbereik. Papias in sy Diēgēseis tōn Logiōn Kuriakōn verklaar namelik dat te Rome Markus, en nie Silvanus nie, die hermèneutès van Petrus was. Wel meld 5:13 ook Markus, maar alleen om te sê dat hy groete stuur en dat Petrus hom waardeer a , ,my seun”. Dit klink meer na die betrekking van Markus tot Paulus in die gevangenskapsbriewe. Nee, die name van Silvanus en Markus en hul betrekking tot die skrywer, skep hier meer probleme as wat hul oplos. Want ook Silvanus staan bekend uit I Thess. 1:1 en II Thess. 1:1 en Hnd. 15:22 as 'n metgesel van Paulus. 
Daarby verklaar die openingsvers van die brief nou dat dit gerig word aan klein-asiatiese provinsies wat met uitsondering van Pontus, Kappadosië en Bithinië, bekende sendinggebiede van Paulus was. 'n Merkwaardige totaalbeeld: 'n Paulusdissipel skryf aan Paulus se sendingsgebied op 'n tydstip toe Paulus na alle waarskynlikheid self in Rome was in die naam van Petrus. Dit $1 y \mathrm{k}$ raaiselagtig. In Rom. 15:20 verklaar Paulus teenoor die Romeine dat hy nie wil bou op die fondament van 'n ander nie. Dis 'n verklaring en dit hoef nie noodwendig as 'n verwyt aan die adres van Petrus gelees te word nie. Maar dan kan mens verwag dat Petrus hom ook aan hierdie gedragskode ten aansien van die sending onder die heidene sou hou. W'aarom skryf hy dan aan die missie-gebied van Paulus? En veral Petrus sou hom wag om nie die allotriēpiskopos (vgl. 4:15) in die gemeentes van andere te speel nie gesien sy eie ervaringe van die kant van die Jakobusmense te Antiochië soos Paulus dit meedeel in Gal. 2.

Maar nie alleen Paulus se Silvanus en Paulus se sendingsveld nie ook Paulus se gedagtes, Paulus se sinswendinge-besonderlik uit sy briewe aan die Romeine met name aan die Romeine en die Efesiërs-word letterlik by die tientalle in I Petrus teengekom. Fr. Hauck het so byvoorbeeld al gewys op die voortdurende gebruik van en Christo in hierdie brief, en dat en Christo in al die rykdom van skakeringe waarin ons dit aantref in die N.T. deur Paulus gemunt is, het Fr. Büchel in sy artikel, In Christus bei Paulus in die Z.N.W. 1949 oortuigend aangetoon. Paulus se taal en teologie val ewe-eens te ontdek in uitdrukkinge soos, dia pisteōs en en tē pistei. (Vgl. I Petr. 1:5; 5:9.) Ef. 5 en Kol. 3 se huistafels weerklink kenbaar in I Petr. 3:1vv. Die beeld van I Petr. 2:4-5 oor die lewende boustene waarmee 'n geestelike huis gebou moet word, bevat op sy beurt herkenbare boustene uit Ef. 2:20-22.

En tog... en tog ontbreek die selfstandigheid van hierdie brieweskrywer in sy brief nie. Wie I Petr. 3:9-14 geskryf het, moes die Bergrede goed geken het. Hy put opsigteliker daaruit as Paulus. In I Petr. 2:9 lees mens die sonderlinge contradictio in terminis, dat die Christene in Klein-Asië 'n ethnos agion is, 'n heilige nasie stellig, maar eintlik, 'n heilige heidendom ... as Godsvolk verkry. Natuurlik ontleen die skrywer dit aan die LXX Ex. 19:6, maar in die situasie van die geadresseerdes neem dit 'n besondere betekenis aan. Dié voorstelling wen aan relief en verstaanbaarheid as mens dit lees teen die agtergrond van Petrus se gesig te Joppe en die begeleidende Godspraak van Hnd. 10:15. Wat God rein gemaak het, mag jy nie onheilig ag nie. En weer, I Petr. 3:19 en 4:6 oor die verkondiging deur Christus aan die geeste van die afgestorwenes, so verwant as wat dit is aan Hen. 6, het met die prediking van Paulus niks in gemeen nie-ook nie met Ef. 4:9 nie. Die herinneringe aan die Bergpredikasie en die uitdrukking, ethnos agion, reflekteer tog iets van die persoon van Petrus.

Dis verder moeilik versoenbaar met 'n paulinis as skrywer dat die woord ekklesia nie eenmaal in I Petr. voorkom nie. Die gebruiklike 
begripsdekking daarvoor in hierdie brief is adelphotēs. By die diskussie moet ook in aanmerking geneem word dat I Petr., naas die briewe van Paulus, die enigste geskrifte is wat in die N.T. self nog genoem word en dan duidelik met die veronderstelling dat Petrus die auteur is, t.w. in II Petr. 3:1. Die feit dat vrywel alle ondersoekers dit eens is dat II Petr. beslis nie deur Petrus geskryf is nie, dien eerder as 'n argument tengunste van die petriniese auteurskap van I Petr. as daarteen: Die gesag van I Petr. moes namelik tog al gou groot gewees het om te kan dien, nog in die tyd van die totstandkoming van die N.T., as aanhaakpunt vir 'n pseudepigraaf. Natuurlik word die feit van hierdie vroeë vermelding weer afgebalanseer deur die ontbreek van I Petr. in die Canon Muratori wat teen 170 gemaak is en met name te Rome, waarvandaan I Petr. geskryf wil wees. Tog weer, I Clem. wat in 96 n.C. in Rome geskryf is, siteer nie bepaald I Petr. nie, maar gebruik in minstens agt instansies woorde en voorstellinge wat sterk ooreenkoms vertoon met dié van I Petr. Natuurlik kan beide geput het uit segs- en voorstellingswyses wat plaaslike gemeengoed was. Dit sou dan ook verklaar waarom mens in Die Brief van Barnabas weerklanke van I Petr. verneem.

Die pro's en contra's vir die petriniese outeurskap is tergend goed gebalanseer. Op die uiterste pole van datering daarvan staan Weiss e.a. wat Petrus outeur wil maak en die brief dus ook vóór 64 geskryf wil laat wees. Daarteenoor staan ondersoekers soos W. F. Beare, dissipel van Hort, wat oor die eerste standpunt oordeel: „The attempts of earlier critics such as B. Weiss and Kühl to argue that our Epistle is prior to the letters of Paul must be regarded as a curious example of critical perversity." Op sy beurt vernuwe Beare dan die vroeëre standpunt van Hort. $\mathrm{H}_{y}$ wys op die merkwaardige ooreenkoms tussen die brief 103 van Plinius Jnr. aan Trajanus en I Petr. Dis inderdaad 'n treffende ooreenkoms en Beare noem nog nie eers al die punte van ooreenkoms op nie. Byvoorbeeld, dieselfde beeld van die Dekaloog wat I Petr. 4:15 bied, tref mens ook aan in Plin. Jnr. se brief: Die ancillae (vroulike diakonoi?) het onder marteling verklaar... affirmabant ... se sacramento obstringere, sed ne furtu, ne latrocinio, ne adulteria committerent, ne fidem fallerent, ne depositum appellati abnegarent. Die beswaar dat daar in Plinius se brief geen verwysing na die doop is nie, ondervang Beare met die opmerking dat I Petr. eintlik uit twee dele saamgestel is, 'n ouere dooppredikasie en dan die latere gedeeltes, wat tydens die vervolginge in Bithinië onder Plinius bygevoeg is. Dis hierdie laaste wat hom daartoe lei om die brief te dateer in 112 na Christus. 'n Beswaar teen Beare se standpunt bly egter dat sy datering te ver weg staan van die tyd van die Brief van Clemens Romanus wat net sulke interessante ooreenkomste met I Petr. vertoon. Sy vergelykingsmateriaal hou inderdaad die moontlikheid in vir 'n vroeëre datering. Plinius rapporteer namelik dat sommige van die wat voor hom aangekla gestaan het as Christene, verklaar het dat hulle wel Christene was, maar dit soveel as 20 jaar al nie meer is nie; d.w.s. sedert 92 n.C., dit wil sê in die tyd van Domitianus en die tỵd ook 
waarin, na die oortuiging van die meerderheid van ondersoekers, Openbaringe geskryf is. Die merkwaardige feit moet hierby vermeld word dat die juis en slegs I Petr. en Openbaringe is wat in die Nuwe Testament na Rome verwys met die kryptoniem, Babilon (vgl. I Petr. 5:13 en Openb. 14:8; 16:19 ens.). Terwyl Plinius duidelik in die onsekere was oor hoe hy dergelike sake moes aanpak, kan mens veronderstel dat hy hom sou verlaat het op vroeëre presedente, dié byvoorbeeld van 20 jaar tevore. 'n Datering teen die jaar 90 lyk o.g.v. hierdie feite nie uitgesluit nie. Natuurlik moet ons dan daarvan afsien om die brief as die werk van Petrus te aanvaar. Maar die pauliniese verwantskappe van die brief wat ons hierbo aangetoon het plus nog die gebruik van die Septuagint in sitate en woordkeus, mak dit ook al wenslik om die auteur te soek in 'n later tyd as 65 n.C. en wel in 'n geruime later tyd, toe die pauliniese briewe en teologie al geleentheid gehad het om te verbrei en inslag te vind.

Wat nou tot hiertoe gesê is, is vantevore ookal op een-of-ander tydstip in een-of-ander verband met die brief gestel. Tensy 'n nuwe weg van benadering van die probleem gevind word, bestaan die kans dat die diskussie in ' $n$ eindelose wentelbaan soos een van die sputniks geplaas word. Lê daar nie miskien in daardie moeilike verteerbare eerste woord van die brief, in die naam Petros, aanleiding vir 'n nuwe benadering van die brief nie? Petrus het namelik volgens die gegewens van die N.T. drie name gedra-Simon of Sumeōn en dan Kepha en tenslotte die Griekse vertaling van Kepha, Petros. Ek meen dis moontlik om aan te dui dat die Apostel die drie name nie gelyktydig gedra het nie, maar in 'n histories nawysbare volgorde op histories-nawysbaar verskillende plekke. Die vraag of Petrus I Petrus geskryf het, sal kragtens hierdie benadering, beantwoord kan word uit die oorweging van die verskillende name wat Petrus op verskillende plekke in verskillende tye gedra het. In die volgende paragrawe sal ek trag om aan te toon dat daar wel so 'n historiese opvolging was in die gebruik van Petrus se name en ons sal daarkragtens kan oorweeg of hy nog tydens sy lewe in die pauliniese gebiede bekend kon gewees het onder die naam, Petros.

„Simon" was die eienaam en die naam waaronder die Oerapostel algemeen bekend was toe hy nog die Galilese visser was wat deur Luk. 5:10 voorgestel word as die koinonos, d.i. ,vennoot", in die visserbedryf van Sebedeüs en Seuns. In die land van sy herkoms het hy, om presies te wees, Shem'on geheet. Dis 'n nie-verbuigende joodse naam wat in die Septuagint, in die Testsment van die Twaalf Patriarge, by Philo en Flavius Josephus dikwels voorkom. En ook in die Nuwe Testament. Twee van Jesus se voorvaders het volgens Luk. 2:25 en 34 Shem'on geheet en Shem'on was die naam van die vrome ou grysaard in die Tempel. Onder hierdie naam het Petrus se vroegste kennisse in Galiléa en in Jerusalem hom geken. Jakobus, die broer van die Here, en latere voorsitter van die sg. Apostelkonvent, noem hom in Hnd. 15:14 nog steeds Shem'on wanneer almal 
anders hom blykbaar al Kepha noem. Daarom moet daar ook meer erns gemaak word met die feit dat II Petr. afkomstig wil wees, nie van Simon Petrus nie, maar van Shem'on Petros.

Dat die naam Shem'on in die geskrewe tradisie al gou uitgewissel word vir die eg-Griekse naam, Simon, maak nie 'n groot verskil nie. Simon is 'n Griekse eienaam wat al by Aristophanes voorkom en toe die Evangelies in literêre vorm gestol het, was die Christendom al oorwegend Griekssprekend en was dit maklik vir die byna gelykluidende Griekse Simon om die joodse Shem'on te verdring. In die vroegste herinnering, byvoorbeeld dié van die ooggetuie in die vierde Evangelie, staan Simon selfs nog bekend met sy patroniem, lōannēs (Joh. 1:42; 21:15). Math. 16:17 vergrieks ook dit na lonas. Dit bly egter merkwaardig dat hierdie eerste naam waaronder die oerapostel ge-introduseer word, nie alleen vir Jakobus die gebruiklike gebly het nie, maar ook vir Jesus. Jesus self het hom die bynaam Kepha gegee, volgens Joh. 1:42, maar tydens sy leeftyd, ook nog na die opstanding, noem Jesus hom steeds op sy eienaam, Simon. Daar is een uitsondering: in Luk. 22:34 noem Jesus hom ook Kepha en wel opsetlik om die teenstelling in relief te bring tussen die Kepha, Rots, waarop $\mathrm{Hy}$ sy Kerk gaan bou en die Simon wat Hom sal verloën.

Naas Jesus en sy broer, Jakobus, skyn ook al die ander dissipels in Jerusalem, minstens nog onmiddellik na die opstanding, te praat van Simon..., „Die Here het aan Simon verskyn” sê hulle aan die Emmaüsgangers (Luk. 24:34). Lukas put hierdie beskrywing uit 'n onmiddellike Jerusalem-tradisie, miskien so onmiddellik as uit die familie van Jesus self. Daar bestaan namelik 'n sterk moontlikheid dat die Emmaüsgangers, waarvan die een Kleopas heet (Luk. 24:18) familie-lede van Jesus was.

Daarna moes daar egter betreklik gou 'n verandering in die benaming van Simon gekom het. Paulus wat hom na sy bekering in Jerusalem gaan spreek het, leer hom dan op daardie tydstip blykbaar ken onder die naam Kepha; in I Kor. 15:4, teen die jaar 52 n.C. herhaal Paulus die Jerusalemgroet woordeliks maar met die naam Kepha in die plek van Simon, ,Hy . . . het aan Kepha verskyn". Dit wil voorkom of Kepha die naam Simon verdring het toe Petrus die leierskap van die gemeente oorgeneem het en die toesegging van Mt. 16:18 in gelding gebring het. Toe het die Kerk Simon begin aanspreek as Kepha. Dit moes in elk geval gebeur het voor Paulus se besoek aan die drie Stuloi waarvan Gal. 2 spreek. Dat Jakobus hom 'n vyftien-tal jare later, tydens die Apostelkonvent, nog steeds Shem'on noem, stry nie teen hierdie gevolgtrekking nie. Verskillende redes daarvoor is al aangebied. A. Deissmann, in sy Bible Studies, suggereer dat die statige Shem'on gebruik is om aan te pas by die plegtige geleentheid en die plegtige toon van Jakobus se toespraak. Miskien. Dit lyk my waarskynliker dat Jakobus hom noem soos hy hom leer ken het by hul eerste sametreffing, m.a.w. soos Jesus en die dissipels te Jerusalem hom genoem het. Wanneer hulle mekaar presies ontmoet het, kan nie meer gesê word nie, maar uit Hnd. 1:13 en 14 val wel op te maak dat dit vóór die hemelvaart plaasgevind het. 'n Ander moontlikheid is dat Jakobus, 
wat al gaande die leiersplek van Simon-Kepha oorgeneem het, nie geneë was om hom met die naam te noem waarop sy leierskap gefundeer was nie, t.w. Kepha. Dat 'n mate van ongerustheid oor die rigting van Simon by Jakobus bestaan het, blyk wel uit Gal. 2:12; Jakobus het inspekteurs agter hom aangestuur na Antiochië. Vgl. ook Hnd. II :2vv.

Met die uitsondering dus van Jakobus en moontlik enkele van sy vroegste mede-dissipels, het almal ná die hemelvaart en Pinkster, die oer-apostel Kepha begin genoem. As Kepha leer ook Paulus hom ken, inderdaad op 'n stadium toe hy al reeds 'n ondergeskikte posisie teenoor Jakobus ingeneem het. As Paulus die ontmoeting beskryf in Gal. 2, noem hy namelik die drie stuloi in die volgorde, Jakobus, Kaipha en Johannes.

Daarvandaan het Paulus nooit anders van sy mede-apostel gepraat nie as van Kepha. Kan dit wees dat hy teenoor Jakobus die Wetsonderhouer, oftewel ho dikaios, dit noodsaaklik geag het om die meerdere gesag van Simon te beklemtoon deur hom te noem met die bynaam wat Jesus self aan hom gegee het te same met die toesegging van die leierskap? Ewe moontlik is natuurlik dat mense oor die algemeen geneig is om vas te hou aan die eenmaal gevormde spreekgewoonte. Paulus het die oerapostel as Kepha leer ken, en as Kepha het hy hom dan by voortduring aangespreek, ookal, soos ons weldra sal aantoon, toe die Kerk buite Jerusalem hom begin noem het op die griekse vertaling van sy naam, t.w. Petros. Gal. 2 vertel ook van spanning tussen Paulus en Petrus oor die rassekwessie in die Kerk te Antiochië. Dit vertel verder van 'n handslag tussen die Stuloi in Jerusalem aan die een kant en Paulus aan die ander kant waarvolgens Paulus na die onbesnedenes sou gaan met die Evangelie en Petrus na besnedenes. Die eerste hoofstukke van I Kor. en ook I Kor. 9 en Gal. 2 laat dink dat Petrus hom nie volledig aan die afspraak gehou het nie maar af-en-toe oor die draad geklim het in die kamp van die onbesnedenes en dit tot ergernis van Paulus. Kaipha se grieksgesindheid begin nog te Jerusalem vorm aanneem en daarmee waarskynlik ook sy mindere gewildheid by die Jerusalemse gemeente en die Jakobusliede. Hand. 6 vertel van 'n dispuut tussen die aramees-sprekendes en die griekssprekendes te Jerusalem: Petrus tree op as arbiter maar sy reëling, hoe billik ook-al, begunstig die Grieks-sprekendes. Die Sewe, wat as versorgers van die Griekssprekendes gekies is, word volgens die volgende hoofstuk al gou die skyf van anti-christelike aanvalle terwyl die arameessprekende buite skot bly. Dis die Griekssprekendes wat daarna uit Jerusalem en Judea gevlug het; hulle word nog agterna gesit tot in Damaskus, en gesien die inspekteurs van Jakobus te Antiochië, neem die Kerk te Jerusalem nie juis deel aan die vervolging nie, maar gee hul wel blyk van hul agterdog. Dis moontlik dat Petrus om rede van sy Grieksgesindheid effens in die aangeklaagde bank staan op die Apostelkonvent. Later verskyn die oer-apostel te Korinthe. En dit lyk of die gemeente uit die heidendom in Galasië hom ook gesien het. Sy welwillendheid teenoor die Griekssprekendes te Jerusalem, in Antiochië, te Joppe en te Caesarea 
haal oor hom die agterdog van Jakobus. Maar sy al te groote toewyding aan die Kerk uit die heidendom maak ook Paulus versigtig teenoor hom. Te Korinthe vorm bepaald ' $n$ party binne die gemeente agter die oerapostel aan. $\mathrm{H}_{y}$ word teen Paulus afgespeel. Paulus is nie 'n oer-apostel nie. Paulus ag dit noodsaaklik om in I Kor. 15 verwytend te vra: Is ek nie 'n apostel nie? Het ek nie die Here gesien nie? Paulus vind dit onder hierdie omstandighede ook noodsaaklik om Petrus nadruklik daaraan te herinner dat by die Jerusalemse ooreenkoms hy, Paulus, vir die heidendom bestem is; meer nog, deur God self daartoe afgesonder is; dat hy alleen inderwaarheid apostolos tōn ethnōn is en dat Petrus apostolos tès peritomès is. Petrus is vir Paulus nie Petros, 'n vertaalde Griek nie, maar Kepha. Met die volharding by die naam Kepha in sy sendinggebiede, wil Paulus die oer-apostel op sy aangewese en ooreengekomde plek hou. Daarom heet die oer-apostel in Paulus se briewe en in Paulus se sendinggebied konstant, Kepha.

Of Petrus self na Hnd. 12:17 (,En hy (Petrus) het daarvandaan weggegaan en na ' $n$ ander plek vertrek") besluit het om voortaan Petros te heet, en of die buite-Palestynse Kerk die vertaling van die naam gemaak het, maak nie groot verskil nie. Uit die feit dat sy hermeneutes, Markus, te Rome die oorwegende naam Petros gebruik, kan mens aflei dat Petros dit so gewil het. Wanneer presies die vertaalde vorm van sy naam die oorwegende geword het, kan mens natuurlik nie presies vasstel nie. Vir die gang van hierdie ondersoek na die name van Petrus en die outeur van I Petr. bly van belang dat hy in Rome, wanneer Markus skryf, Petrus heet maar dat hy in die klein-asiatiese gemeentes nog al die tyd en miskien deur die opset van Paulus, Kepha heet. Dit maak nie veel uit dat hy ook deur Paulus, maar dan ook net eenmaal一in Gal. 2:7, 8 Petros genoem word nie. Of, soos al gesuggereer is, haal Paulus hier uit 'n dokument aan, óf Paulus gebruik dit in sy polemiek teenoor die Judaiste ironies.

Ons het dan nou nageloop die ewolusie in die name waarmee die oer-apostel genoem is van Shem'on, langs Kepha tot by Petros en ons het die tye en die gebiede waarin die name oorwegend gebruik is, gekonstateer. En nou dan die outeurskap van I Petr. Ons kon vasstel dat die naam, Petros eers in Rome in die Evangelie van Markus algemeen gebruiklik geword het. D.w.s. in die sestiger jare. Ek meen dat na die indringende ondersoek van Cullmann dit nie meer nodig is om opnuut aan te wys dat Petrus wel in Rome was en wel in Rome gesterf het op die nag van die 19de Junie 64 n.C. nie. Toe Paulus aan die einde van die vyftiger jare sy brief aan Rome skryf, was Petrus nog nie daar nie. Die vestiging van die naam Petrus het dus vir die eerste keer in die eerste helfte van die sestiger jare plaasgevind.

Die historiese beeld wat I Petrus ons voorhou is dat Petrus daarvandaan geskr $\mathrm{f}$ het in vervolgingstyd, sodat dit selfs nodig was om na die hoofstad te verwys met die kryptoniem, Babilon. Die vervolginge onder Nero word ge-impliseer. Dis alles goed en wel, en dit kon, gesien uit die naam waaronder die apostel in die hoofstad bekend was, histories 
ook moontlik gewees het. Alleen, die gemeentes waaraan die brief gerig is, pauliniese sendinggebied, ken hom nie onder die naam Petros nie en sou ook nie begryp wie die afsender, Petros, was nie. Hulle ken die naam Kepha. Ons meen daarom te moet aanneem dat gesien die kort bekendheid van die naam Petros en gesien tweedens dat sy naam in Klein-Asië nog al die tyd Kepha was, die studie van die ewolusie van sy name, aanwys dat Petrus wat in 64 gesterf het, onmoontlik self nog die brief wat op sy naam staan, geskryf het. Dit kan wees dat Silvanus dit geskryf het, maar dan wat Petrus betref, posthuum. Van Unnik, De Verlossing in I Petrus. Bls. 55 en 90 laat 'n datering tot 70 n.C. toe. Danksy die Evangelie van Markus kon die naam Petrus en ook sy gesag al so universeel verbreid gewees het, dat Silvanus goedskiks onder daardie naam aan voormalige pauliniese gebiede kon skryf. Van Unnik se opvatting kan tref ten aansien van I Petrus 1:18 en 19, maar Beare maak 'n gunstige saak uit vir die moontlikheid dat die brief, soos aan ons oorgelewer, uit 'n oorspronklike stuk doopprediking bestaan wat 1:18 en 19 insluit, en 'n tweede stuk behelsende die prescriptum en die slotgedeelte vanaf $4: 12$. In dié geval kan die feit dat in die N.T. alleen I Petr. 5:13 en die Apokalyps die kryptoniem, Babilon, gebruik, meespreek tengunste van 'n datering in die tyd van die Apokalyps self. In die tye van martyrium gaan die gedagtes vanself na die persone en die gesag van die klassieke martyres uit. Dit dui op 'n vervolging en 'n publikasie van I Petr. in sy huidige vorm, in die vroeë negentiger jare. En so 'n datering klop met die opmerking van Plinius Jnr. in 112 n.C. dat sommige van die aangeklaagdes in Bithinië en Pontus al 20 jaar te vore hul Christenskap afgelê het, d.w.s. teen 90 n.C.

A. S. GeYser. 